\title{
Small and Medium Business Management-Financial Sources and Difficulties
}

\author{
${ }^{1}$ Anthony Abiodun Eniola, ${ }^{2} \mathrm{Dr}$. Harry Entebang \\ Department of Business Management, Universiti Malaysia Sarawak \\ E-mail address: 1'tony42003@yahoo.co.uk (corresponding author); ${ }^{2}$ harryentebang@yahoo.com
}

Keywords: financing, SME, performance, Nigeria

\begin{abstract}
SMEs has performed an unparalleled role in coming to the Nigeria economic growth and assist as a training ground for entrepreneurs and a provider of solutions to address the challenges of unemployment in all consuming labours and promoting marketing growth. An opportunity for the wholesome advancement of SMEs in Nigeria was in connection to the sea change and growth policy as a consequence of the rapid advancement of the global economic system. But with the world economic unification, SMEs business environment is facing tremendous changes and more intense competition. Hence, the reason for this study is to confront the sources of SME firm financing, conceptualise its financial challenges and source causes with objectives to exploit the increase and advancement of SMEs prospectively.
\end{abstract}

\section{INTRODUCTION}

Small and medium enterprise sector growth performance is essential to the nation performance. The vast majority of businesses globally are SMEs and functions a tract for entrepreneurs and a source of resolution to cope with the unemployment issue in all consuming labours and promoting marketing growth. The importance of SMEs in the evolution of economic, reduction in poverty, increase in value added, innovation, job creation, and boost in social position and standard is globally proven and acknowledged in emerging as well as in developed economies [1]. Accordingly, SMEs have been recognised to have a prodigious capacity for tenable development [2]. The surfeit of the employee's manpower from the larger corporation had the capacity be restored back to the employment, mainly through the growth of SMEs. To maximise performance, firms rely upon a range of sources of finance [3]. Resources and strategic choices as internal factors, and carrying capacity of the environment or compete as external factors, affects firm performance. The resource-based view of the firm proposed that competitive advantage arises from the ownership and deployment of resources that are in some way superior to those of its competitors. Accessing financing has been accentuated as the foremost constraints poignant the performance and development of small business in Africa. According to Fadahunsi [4] due to a shortage of financing provision and entrepreneurial skills, there is a high mortality rate of SMEs in Africa.

Financing, according to Mukhtar [5] is a precondition to the performance of enterprises. Hence, far, Nigeria has a great number of SMEs, playing a substantial part of the economic system. There are many different ways firms financing their operations and growth. Their financing alternatives are determined by the predilections of each firms entrepreneurs and, more essential, by the options that are reachable to them. However, in achieving growth, they try to overcome various challenges. According to Beck and Demirguc-Kunt [6], SME firms' still experiences various difficulties boosting developmental growth, particularly in financing. This study essentially considers its financing difficulties from the area of financing provision sources, which is of outstanding import for the SMEs firm performance and improve Nigeria economy. 


\section{LITERATURE REVIEW}

\subsection{SME Definition}

A critique of the literature on SMEs indicates that the definition of SMEs considerably differ from nation to country count on elements such as the country's; number of employees, the value of fixed assets, production capability, basic characteristics of the inputs, applied technology, and the essential challenges experienced by SMEs [7, 8]. On this certitude, it is very arduous of comparing SMEs among different nations. From the angle of the employee size, as their distinctive criteria for defining SMEs, scholars and other concerned parties have used distinct touchstone to operationalise the small business. SMEs in Nigeria is defined according to firm employment size and turnover base.

\section{SME FIRM AND SOURCES OF FINANCING}

According to Shepherd [9], credit decides access to all or any of the resources that SMEs owners/manager rely upon. It is a supply of funds to SMEs that may be used in the production and sustaining a firm competitive advantage process [10]. The need for financing in SMEs might emerge from four causes. Firstly is the need for start -up capital to assist in the formation of a new venture. Adopted by the necessity to finance business expansion through the leverage of new buildings, plants or machinery, finance working capital and trade debtors. Capital likewise may be needed for carrying over the extant line of work as an expansion strategy. Moreover, is when a venture capital is required to finance innovation. This requirement might occur independently or to coincide with the above-mentioned occasion. This type of financing is called risk capital, bears a significant degree of risk attached; so, it usually takes a great reward. Finally, is to adapt the existing financial structure of the business via changes in the remainder of equity to debt or the ratio of long to short-term debt. Capital is one among the means for enterprises to get financing provision. This paper categorise financing, according to its sources.

\subsection{Internal and External Sources}

Internal financing is classified as a means of enterprises used own fund together with plowback and depreciation, that is an important aspect of the continuation and growth of the business venture. Predominantly, an important first choice to source capital is via internal financing. Previous researchers, scholars and practitioners, Gélinas [11]; Ojo [12]; Pretorius and Shaw [13] identified two underlying financing conception of SMEs, the internal and external financing. Business financing can come either from internal or external sources $[3,11,13]$. Yet, a lot profitable SMEs makes used of financial institutions, individual investors, venture capital, and crowdfunding as external sources of financing and then make out fewer successful firms. According to Fischer and Reuber [14] external resource providers are a central component for rapid development. Carpenter and Petersen [15] find that SMEs use a more internal sources of financing and this constrained their performance.

Steel, et al. [16] posits that informal finance as all financial transactions that take position outside the operational range of various country's banking and other financial laws that cover a good assortment of financial activities whose scope of operations could take issue from country to country. Access to financing is the major determinant of business start-up and performance of SMEs.

\subsection{Formal Source of financing}

Commercial banks, merchant banks, and development banks are the established sources and provider of formal funding for SMEs. This set as a financial organisation with the purpose of profit acquisition, run by the states or independent capitalist. In an attempt to get this core purpose of banks, a number of functions were performed. One of the actions is the upset of the adoption of deposit as a credit to entrepreneurs and businessmen for productive uses. The financial scheme in Nigeria is not in short supply of liquidity, but banks have been very loth to give loans to SMEs, which they see as a high risk sector. It is mentioned that the bank credit is important for the take- 
off and efficient operation of any commercial enterprise. Such an enterprise may be in any form or size. It is equally required to coordinate other factors of production besides the initial demand for capital for investment purposes. Bank credit influences SME firm performance positively which transmit to the tier of economic activity in the state. Likewise is capable of deciding what is to be produced, for whom and how to be produced and even at what price the good or services is failing to be available to consumers. For instance, a study found in Ghana and Kenya, banks curb themselves to overdrafts and to medium-term bank loans. Besides, both types of credits were not granted without collateral. Consequently, financing provision through banks is largely confined to medium and large firms with secure collateral [17]. Over the years, the ratios of commercial bank loans to SMEs total credit have continued to decline almost uncontrollably. Hence, the need for a financing option of SMEs in the country which is readily obtained in the non-financial institutions.

\subsection{Informal sources of financing}

Informal source of financing refers to the financial transactions that occur outside official financial institutions. These transactions are not regulated by governmental authorities. It is important to note that the definition of informal financial transactions has nothing to do with legality issues. Unlike formal institutions, such transactions rarely use legal documentation or the legal system to enforce contracts. Steel et al. [16] attempts an all-embracing working definition of informal finance as 'all financial transactions that take place outside the functional scope of various countries banking and other financial regulations that include a wide range of financial activities whose scope of operations may differ from country to country'. According to Pagura and Kirsten [18] informal financial transactions can be legal such as borrowing from family members or can be forbidden by the law such as moneylender activities as in many countries.

Informal credit sources are heterogeneous, such as loans from money lenders, traders, families and friends, so on, account for between one-third and three-quarters of total credit in Asia [19-21]. The informal financial institutions exhibit different characteristics. Some of their common characteristics can be summarised as: dependence mostly on relationships and social networks, different interest rates from formal interest rates, generally small and short-term loans, small or no collateral, no regulation, no registry, and no deposit insurance.

The promotion and development of informal financial institutions were to checkmate the inefficiencies that were observed in the formal financial institutions. Borrowers in informal financial markets are generally the agents who have difficulty accessing finance or excluded from formal financial services, mostly SMEs and poor households, informal businesses, or borrowers in those rural areas are located far from formal creditors, people who are not able to meet collateral requirements. In this sense, the existence of informal financial markets is attributed to credit rationing or in a broader sense to credit constraint phenomena.

Previous empirical studies show that, despite financial liberalisation efforts and regulations, informal credits still constitute a large proportion of credits, especially that are provided to SMEs. Tsai [22] indicated that there is still extensive of informal financial institutions in China and India in spite of authorities' heavy control and regulations. He further indicated that the meagre provision of bank credit, limits in governmental capacity to enact its policies, the political and economic division of the local market, and the institutional failings of many microfinance programmes as the genes that contribute to the continuity of the informal financial sector. According to Ekpenyong and Nyong [23], there is a wide consensus in Nigeria that government policies are skewed in favour of the formal sector to the detriment of the informal sector. This asymmetry is to the good disadvantage of SMEs in Nigeria since they additionally dispose of the funds of the informal sector. Also, Steel, et al. [16] the liberalisation had little effect to undermine informal financial sector in Nigeria and other developing African countries.

\subsection{Debt Financing}

Debt financing can be obtained from two sources, formal and informal sources. Formal sources are usually viewed as institutional sources, whereas informal sources refer to family, friends, 
directors, trade credit, and so on. Debt financing occurs when investors provide capital in the shape of loans for the managers/owners of a company to use to run the line. The firm, in return, pay interest rate for the use of the credit of the capital borrowed from the investors. Smaller firms, which require external finance, prefer to use debt funding from lending institutions as provenance, especially banks, are the most popular source of debt finance [24, 25]. Information asymmetries and moral hazard have a pronounced impact on banks and other finance providers, particularly at the start-up level. This is because of the lack of collateral and market presence; characterise most hightech start-ups. Bank wants the firm to have collateral, an asset that is utilised to guarantee the loan, but this requirement often is negotiable. If a firm is having difficulties meeting its obligations, it is normally more comfortable to negotiate new terms to bank financing than for issuing securities. This flexibility results from the ongoing relationship between the bank and the firm.

\subsection{Equity Financing}

Equity financing is one provenance of financing provision a firm may employ to finance its business operations [26]. Equity financing is received in return for a proportional portion of a firm's value. It's the net worth of a firm; the value of the assets less the value of the financial obligations. The value of the equity of a concern is whatever remains after the company fulfils all of the claims of its creditors (residual claim). Equity capital can be furnished by the proprietor or by the directors of the firm, known as internal equity. Internal equity can also be supplied via profits made and retained by the business. As a matter of choice, third parties equity can be supplied, external equity.

External equity is the means of raising capital through the sale of shares in a company. Equity financing essentially refers to the sale of an ownership interest to advance finances for business functions. Equity financing spans a broad range of activities in scale and scope, from a few finances raised by an entrepreneur from friends and family, to giant initial public offerings (IPOs) running to raise huge capital. While the condition is mostly associated with financings by public companies listed on the stock exchange, it includes financings by private companies likewise. Equity funding is apparent from debt funding that refers to the funds borrowed by a business.

The huge bulk of SMEs in developing countries see their financial need through ownermanager's personal savings [27]. Other works, nevertheless, testified that an internally generated profit has been the most often used sources of finance, especially for mature small firms [28-31]. Due to the high cost of obtaining external finance, it was found that the majority of small innovative firms relies heavily on internal profits as the main source of investment capital; they were reluctant to rely on external funding because of risks associated with the onerous terms demanded by external lenders of money. Firm owners were generally not averse to external assistance per Se since, it was clearly a means of expanding their businesses at a faster rate. However, in practice it was generally believed, both in developed nation like Britain and the United States, that the burden of risk was heavily biased in favour of the firm owner, while returns to the lender, partly due to this unbalanced risk, were excessive. Although the majority of small businesses relies primarily on personal savings for start-up, most of them still need access to external finance, either equity or debt so as sustaining or developing. As businesses expand and enlarge they considerably cut back their dependency on personal savings and diversify their sources of external finance [28].

\subsection{Short-Term Financing}

Short-term financing is determined as a loan or credit facility with a maturity of a year or less. It as well defined as a credit arrangement extended to a mortgage banker to finance an inventory of loans that are resold to investors. Because of the difficulty in raising adequate finance for expansion, Bates and Hally [32] revealed that small firms are often driven to access short-term and medium-term sources of financing at high costs in condition of overdraft, trade credit, credit cards, leases and bank loans. While small firms are found to be moving from depending on short-term towards long-term finance; they are still greatly relied upon short-term bank loans and overdrafts to finance their business activities and operation [24, 33]. 
A survey of debt pattern in developed countries as reported by OECD [34] scorecard indicator, found that small and entrepreneurial firms in the UK depend too greatly on overdrafts as a choice source of financing. Three-quarters of the debt of small British firms were either overdrafts or other sorts of short-term loans, and overdrafts alone accounted for 58 percent of total debt compared with 35 per cent in Italy and just 14 per cent in Germany. Dimson [35] in his research on the sources of finance required by the smaller companies pointed out that small firms have a significantly higher proportion of current assets within total assets compared to large firms. His observation showed that small firms rely heavily on current liabilities, mainly trade credit. Trade credit was found to be the next major source of debt finance after overdrafts [24]. In defiance, business financing in Chile, France, Korea, Russia, Serbia, Slovenia and Switzerland has been advancing. While Turkey within a context of 2010-2011, due to the overall expansion of business lending at different rates, experienced continued growth in SME [34].

\subsection{Long-Term Financing}

Long-term financing is a form of financing that is provided for a period of more than a year [26]. It is a financial obligation lasting over one year. It would include any financing or leasing obligations that are due to come in a greater than a 12-month period. Long-term financing services are provided to those business entities that face a shortage of capital. Long-term financing is generally for assets and projects and short-term financing is typically for continuing operation. It is distinct from short-term finance that is generally accustomed to offer cash that has to be paid back in twelve months. Likewise, the length of time may be shorter than twelve months. Long-term financing includes a 30-year mortgage or a 10-year treasury note, like when an organisation issues stock put up capital for a new investment. Equity is a one mean of long-term financing.

Broadbent and Cullen [36] observed that sources of long-term financing include shares, debentures, public deposits, and retained earnings, term loans from banks and loans from financial institutions. Shares are authorised to the general public. The shareholders are the business owners. These may be of two types Equity and Preference. Debentures are also issued to the general public. The holders of debentures are the creditors of the company. Public deposits come about since the general public also like to deposit their savings with a popular and well-established company which can pay interest periodically and pay back the deposit when due. Retained earnings since have arisen the company may not distribute its profits' whole among its shareholders. It may retain a part of the profits and utilise it as capital. Term loans from banks are a consequence of many industrial development banks, cooperative banks and commercial banks granting medium-term loans for a period of three to five years. Finally, loans from financial institutions result from the many specialised financial institutions established by the central and state Governments which give longterm loans at a reasonable rate of interest.

\section{SME FINANCING SITUATION IN NIGERIA}

Financing of SME's in Nigeria has been a prickly topic. Capital is essential to the success of a business enterprise as it forms the foundation of the business. Nwachukwu [37] submits that SMEs performance in Nigeria have not yielded the expected results and desired impact on the development growth and this may not be unconnected to the financing challenges. Claessens [38] affirms that one of the issues linked to accessing financing acknowledge to the questioning, whether financial services are available and in what quantity. The phenomenon of SME financing difficulty exists in many countries in the world, even in the developed countries with the relatively sound financial system, but this phenomenon in Nigeria is particularly prominent.

The Table 1 below shows that SMEs in Nigeria, firms always relies on retained earnings. While according to Idowu [39] SMEs rely on overdraft to finance long- term investments, and these have to be fully collateralised. Ogbuabor, et al. [40] examined the historical trend in the development of SMEs in Nigeria and observed that various opportunities that can contribute to competitive advantages are now only reserved for Nigerian companies. The survey underscored the demand for access to funding for development of the capital base of SMEs, and indicated that the Act would 
offer a turning point in the recognition of all the policy trusts formulated for growing SMEs in Nigeria in the hereafter. Despite their performance dominant numbers and importance in job creation, SME has always faced difficulty in obtaining formal credit or equity from financial markets.

According to ECA [41] even access to this overdraft and short-term loans are extremely restricted. In the study carried out in Nigeria by the [42], roughly 70 per cent of respondents utilising commercial banks overdraft facilities with lower interest rates were needed to pledge collateral in the cost of land (48 per cent), Building ( 31 per cent), fixed asset, such as machinery (35 per cent) and other assets ( 8 per cent). It is to be taken down that table above does not include longterm financing. For long-term financing of an entrepreneur, supplier credit is not an option, so firms tend to rely on own funds over 90 per cent of the time.

Empirical studies such as Wiklund and Shepherd [43]; Zou and Chen [44] identify that SMEs need financial capital to obtain physical resources in order to take advantage of business opportunities. Sanusi [45] showed that SMEs accessibility to formal financing in Nigeria is very limited. To build and sustain an SME, the entrepreneur requires to accessing varying forms of resources, like human capital; physical capital; and financial capital, each playing same significant, but different purposes during the life cycle of a new SME [46].

Table 1: Sources of Financing: International Comparison

\begin{tabular}{|c|c|c|c|c|c|c|c|}
\hline $\begin{array}{l}\text { Percentage of short-term financing } \\
\text { from : }(\%)\end{array}$ & $\begin{array}{c}\text { Nigeria } \\
2008 \\
\%\end{array}$ & $\begin{array}{c}\text { Brazil } \\
2003 \\
\%\end{array}$ & $\begin{array}{c}\text { China } \\
2003 \\
\%\end{array}$ & $\begin{array}{c}\text { India } \\
2005 \\
\%\end{array}$ & $\begin{array}{c}\text { Indonesia } \\
2003 \\
\%\end{array}$ & $\begin{array}{c}\text { Kenya } \\
2007 \\
\%\end{array}$ & $\begin{array}{c}\text { S. Africa } \\
2003 \\
\%\end{array}$ \\
\hline Internal funds/ retained earnings & 70 & 44 & 13 & 47 & 38 & 73 & 66 \\
\hline $\begin{array}{l}\text { Borrowed from banks and other } \\
\text { financial Institutions }\end{array}$ & 1 & 30 & 27 & 32 & 16 & 7 & 17 \\
\hline $\begin{array}{l}\text { Purchases on credit from suppliers } \\
\text { and advances from customers }\end{array}$ & 25 & 15 & 2 & 9 & 4 & 17 & 12 \\
\hline $\begin{array}{l}\text { Borrowed from family, friends and } \\
\text { other informal sources }\end{array}$ & 4 & 5 & 8 & 9 & 20 & 3 & 1 \\
\hline Issued new equity/debt & - & 4 & 12 & 2 & 2 & - & 1 \\
\hline
\end{tabular}

Source: Isern, et al. [47].

In this regard, the findings showed that the SMEs sector in Nigeria is still weak, starved of funds (Chukwuemeka, 2006; Fadahunsi, 1997; Kadiri, 2012; Mahmoud, 2005; Sule, 1986) and its level of funding (LOF) is one of the lowest in the world (CBN, 2006; MAN, 2011). Some authors have studied SMEs difficulties in accessing finance (demand side characteristics) while others have presented the main issues in bank lending practices (supply side characteristics). Understanding why SMEs face a financing gap, commonly defined as the difference between the volume of funds at their disposal and the volume of funds they require, implies distinguishing the various limitations which describe both sides. The supply side impediment is noticeable when the terms and conditions are not suitable for SMEs; the apt sources of finance are not accessible. The demand side constraints exist if entrepreneurs do not make use of existing financing opportunities, because of a shortage of good projects, lack of financing literacy, lack of persuasive business plans or lack of collateral presentation [48].

\section{SOURCES OF FINANCING CHALLENGES}

The occurrence of SME financing snag is brought along for numerous reasons, for instance, corporate itself issues, banks points of restriction, and credit establishments. This work centres its financing sources specifically financing strategy to break down financing challenges of SME. Because of the Nigeria financial institutions' framework, to prepare for monetary hazards, commercial banks changed their lending improvement procedure to favour large businesses. These developments created SMEs found with a smaller size in number or organisation to experience issues in getting funding facilities. Furthermore, it's nevertheless a huge challenge for SME getting bank advances regarding bank credits structural, viability and maintainable quality. On the supply side collateral guarantee is the main standards for loan approval, additionally, bank credit keeps on 
inclines towards substantial venture or SME firm that run well, also, long-time credits are amazingly low. This lopsided structure has obstructed the maintainability of SMEs with most likely, subsequently; prompt inept loaning, paucity of credit overseeing and assessment of SMEs framework. Small and medium-sized credit establishments are not many, as far as the current state of affairs of financial establishments in relation to SMEs, and face numerous issues and challenges in its further advancement, hence are unable to content the SMEs. The weak credit financing and non-subjective or mortgage asset resources, considered by banks makes it more significantly challenging in raising financing provision. Likewise, the no third-party undertakings with ample credit rating assessment to provide guarantees, making it reliable for funds obtainable from banks. The distance between the entrepreneur and the bank also determines the transaction costs. Geographic proximity between a bank and borrower facilitate frequent face-to-face communication and, subsequently, increases a strong bank relationship. SMEs located in rural areas of Nigeria, lag behind their urban areas, due to the high risk associated SMEs, there is a persistent lack of bank loans for rural entrepreneurs. Hence, financing institutions still have incredible breaking points for SMEs in fund raising. To circumvent these problems, the missing middle brings innovation in financing provision sources for SMEs in terms of crowdsourcing for funds.

\section{CONCLUSION}

The important drive of sustained Nigeria's developing economy is SMEs. In financing sources, SMEs can adopt the various method. It is imperative for an SME firm to be innovative in choosing right and suitable financing sources to combat the organisational financial challenges. This work majorly analyses the financial innovation and the movements of fiscal challenges from its sources, determine that fewer bank loans issue, geographical issues, and that absence of uniformity in public funds has hampered the profitable funding of SMEs. Likewise, the study looked at various means of financing SMEs and observed that there is still low of external financing provision for an SME firm in Nigeria.

The survey proposed that one of the innovative ways for SME firms becoming increasingly significant and invaluable in advancing economic growth in Nigeria is to improve financing provision via refinement of the financing sources. Nevertheless, in that respect is the need for government to provide a conducive environment that will enhance different financing sources. This review is one of a few studies that approached this matter. This study will add to the existing literature in the academic field of entrepreneurial finance and at the same time offers a springboard that will provide an impulsion for empirical inquiry in this area. It will help the policy maker in making SMEs becoming increasingly significant and unique in advancing economic development in Nigeria.

\section{References}

[1] A. A. Eniola and H. Entebang, "SME Firm Performance-Financial Innovation and Challenges," Procedia - Social and Behavioral Sciences, vol. 195, pp. 334-342, 7/3/ 2015.

[2] A. A. Eniola and H. Entebang, "SME firms performance in Nigeria: Competitive advantage and its impact," International Journal of Research Studies in Management, vol. 3, pp. 75-86, 2014.

[3] A. Terungwa, "Risk Management and Insurance of Small and Medium Scale Enterprises (Smes) in Nigeria," International Journal of Finance and Accounting, vol. 1, pp. 8-17, 2012.

[4] O. Fadahunsi, "The Challenge of Promoting Entrepreneurship and Small Business: The Commonwealth Experience " in Small and Medium Enterprises Development: Policies, Programmes and Prospects O. Fadahunsi and T. Daodu, Eds., ed: West African Management Development Institutes Network (WAMDEVN) 1997, pp. 170 - 186. 
[5] S. M. Mukhtar, "ICT-driven human and knowledge capital development: in search of a new economic development model and policy framework in the networked global economy," $J$. for International Business and Entrepreneurship Development, vol. 4, p. 74, 2009.

[6] T. Beck and A. Demirguc-Kunt, "Small and medium-size enterprises: Access to finance as a growth constraint," Journal of Banking \& Finance, vol. 30, pp. 2931-2943, 2006.

[7] A. Enquobahrie, "Promoting Entrepreneurship and Small Business in Cameroon," ed, 1997.

[8] N. Harabi, "Determinants of Firm Growth: An Empirical Analysis from Morocco," ed, 2005.

[9] W. G. Shepherd, The economics of industrial organization. Englewood Cliffs, NJ: PrenticeHall, 1997.

[10] K. M. Eisenhardt and J. A. Martin, "Dynamic capabilities: what are they?," Strategic Management Journal, vol. 21, pp. 1105-1121, 2000.

[11] J. Gélinas, Freedom from debt: The reappropriation of development through financial selfreliance. London; New York; New York: Zed Books Distributed in the USA by St. Martin's Press, 1998.

[12] A. T. Ojo, Banking In Nigeria, 1984.

[13] M. Pretorius and G. Shaw, "Business plans in bank decision-making when financing new ventures in South Africa," South African Journal of Economic and Management Sciences = Suid-Afrikaanse Tydskrif vir Ekonomiese en Bestuurswetenskappe, vol. 7, pp. p.221-241, 2004.

[14] E. Fischer and A. R. Reuber, "Support for Rapid-Growth Firms: A Comparison of the Views of Founders, Government Policymakers, and Private Sector Resource Providers," Journal of Small Business Management, vol. 41, pp. 346-365, 2003.

[15] R. E. Carpenter and B. C. Petersen, "Capital Market Imperfections, High-Tech Investment, and New Equity Financing," The Economic Journal, vol. 112, pp. F54-F72, 2002.

[16] W. F. Steel, E. Aryeetey, H. Hettige, and M. Nissanke, "Informal financial markets under liberalization in four African countries," World Development, vol. 25, pp. 817-830, 1997.

[17] M. Fafchamps, T. Biggs, J. Conning, and P. Srivastava, "Title," unpublished|.

[18] M. Pagura and M. Kirsten, "Formal-informal financial linkages: lessons from developing countries," Small Enterprise Development, vol. 17, pp. 16-29, 2006.

[19] J. Weiss and H. Montgomery. (2004). Great expectations: microfinance and poverty reduction in Asia and Latin America.

[20] J. Conning and C. Udry, "Chapter 56 Rural Financial Markets in Developing Countries," in Agricultural Development: Farmers, Farm Production and Farm Markets. vol. 3, P. H. o. a. e. Evenson, Ed., ed: Elsevier, 2007, pp. 2857-2908.

[21] D. A. Germidis, D. Kessler, and R. Meghir, Financial systems and development: What role for the formal and informal financial sectors? Paris: Development Centre of the Organisation for Economic Co-operation and Development, 1991.

[22] K. S. Tsai, "Imperfect Substitutes: The Local Political Economy of Informal Finance and Microfinance in Rural China and India," World Development, vol. 32, pp. 1487-1507, 2004.

[23] D. B. Ekpenyong and M. O. Nyong, Small and medium-scale enterprises in Nigeria: Their characteristics, problems, and sources of finance. Nairobi: African Economic Research Consortium, 1992.

[24] K. Keasey and R. Watson, "The bank financing of small firms in UK: Issues and evidence," Small Business Economics, vol. 6, pp. 349-362, 1994.

[25] J. M. Samuels, F. M. Wilkes, and R. E. Brayshaw, Management of company finance, 6th ed ed. London: International Thomson Business Press, 1997.

[26] R. C. Higgins, Analysis for financial management, 10th ed ed. New York, NY: McGrawHill/Irwin, 2012.

[27] B. Levy, "Obstacles to Developing Indigenous Small and Medium Enterprises: An Empirical Assessment," The World Bank Economic Review, vol. 7, pp. 65-83, 1993. 
[28] C. Mason and R. Wilson, "Conceptualizing financial literacy," Business School Research Paper, 2000:7, Loughborough University, 2000.

[29] J. Blake and P. A. Lawrence, Small business breakthrough. Oxford, UK; New York, NY, USA: B. Blackwell, 1985.

[30] E. B. Roberts, Entrepreneurs in High Technology: Oxford University Press, 1991.

[31] R. P. Oakey, New technology-based firms in the new millenium: Vol. 7, Online-Ausg ed. Bingley, U.K: Emerald, 2009.

[32] J. A. Bates and D. L. Hally, The financing of small business, 3rd ed ed. London: Sweet \& Maxwell, 1982.

[33] J. Stanworth and C. Gray, Bolton 20 years on: The small firm in the 1990s. London: Chapman Publ, 1991.

[34] OECD, "Recent Trends in SME and Entrepreneurship Finance," 2013.

[35] E. Dimson, "Financing the smaller company," Long Range Planning, vol. 11, pp. 9-13, 1978.

[36] M. Broadbent and J. Cullen, Managing financial resources, 3rd ed ed. Oxford; Boston: Butterworth-Heinemann, 2003.

[37] Nwachukwu, "The Role of Entrepreneurship in Economic Development: The Nigerian Perspective," European Journal of Business and Management, vol. 4, 2012.

[38] S. Claessens, "Access to Financial Services: A Review of the Issues and Public Policy Objectives," World Bank Research Observer, vol. 21, pp. 207-240, 2006.

[39] F. C. Idowu, "Impact of Microfinance on Small and Medium-Sized Enterprises in Nigeria," in Proceedings of the 7th International Conference on Innovation \& Management, 2010, pp. 1864-1871.

[40] J. E. Ogbuabor, V. A. Malaolu, and T. I. Elias, "Small Scale Enterprises, Poverty Alleviation and Job Creation in Nigeria: Lessons from Burnt Bricklayers in Benue State," Journal of Economics and Sustainable Development, vol. 4, 2013.

[41] ECA. (2001, 20/12/2014). Enhancing the competitiveness of small and medium enterprises in Africa: a strategic framework for institutional support. Available: http://repository.uneca.org/handle/10855/3324

[42] USAID. (2005). Micro, Small and Medium Enterprises Financial Services Demand Survey Nigeria[

[43] J. Wiklund and D. Shepherd, "Entrepreneurial orientation and small business performance: a configurational approach," Journal of Business Venturing, vol. 20, pp. 71-91, 2005.

[44] H. Zou and X. Chen, "Resources, Capabilities and New Venture Growth Choice," 2008.

[45] J. O. Sanusi, "Overview of Government's Efforts in the development of SME's and the Emergence of Small and Medium Scale Industries Equity Investment Scheme (SMIEIS)," in Paper presented at the National Summit on SMIEIS organized by the Banker's Committee and Lagos Chamber of Commerce and Industry (LCCI), Lagos, Nigeria, 2003.

[46] O. Fatoki, "The Financing Options for New Small and Medium Enterprises in South Africa," Mediterranean Journal of Social Sciences, 2014.

[47] J. Isern, A. Agbakoba, M. Flaming, J. Mantilla, G. Pellegrini, and M. Tarazi, "Access to Finance in Nigeria: Microfinance, Branchless Banking, and SME Finance," ed: CGPA/World bank, 2009.

[48] OECD, "small and medium sized enterprises in turkey issues and policies," Organisation for Economic Co-operation and Development (OECD)2004. 